\title{
The Effect of Human Capital, Motivation and Job Satisfaction on Employee Performance: A Literature Review
}

\author{
Slamat Jeki ${ }^{1}$, Sulastri Sulastri ${ }^{2}$ \\ 1Universitas Negeri Padang, Padang, Indonesia, $\square$ slamatjeki80dhirgan@gmail.com \\ ${ }^{2}$ Universitas Negeri Padang, Padang, Indonesia, $\bowtie$ sulastri.feunp@gmail.com
}

\begin{abstract}
s
This paper is a literature study to analyze the effect of human capital, motivation and job satisfaction on employee performance. This type of research is explanatory research, looking at the relationship among free variables human capital, motivation, and job satisfaction on employee performance. The purpose of this study is to collect and analyze the published articles regarding the effect of human capital, motivation, and job satisfaction on employee performance. The research design is a literature review. The articles have been published in the last five years representing of six different academically. The results of the review literature find out that human capital, motivation, and job satisfaction has a positive and significant effect on employee performance. The results of this review are only a conceptual starting point for starting an integrated discipline.
\end{abstract}

Key Words: human capital, motivation, job satisfaction, job performance

\section{Introduction}

In the current era of globalization, there is a very rapid development of technology and information. This development resulted in intense competition in the industrial world. Every organization has a goal to be able to compete well in accordance with the development of globalization and modernization today. For this reason, a good system is needed for every organization. One of them is having quality human resources and professionals in their respective fields because human resources are very instrumental in carrying out the activities of the organization. Human resources are one of the most valuable assets of an organization and one of the determinants of the survival of an organization in the future. Therefore, a leader must be able to manage resources effectively and efficiently, especially in managing human resources. With the presence of good performance, human resources are expected to be able to realize the desires and goals of the organization. The problem of employee performance in human resource management is the main problem that must get the attention of the organization. Employee performance is considered important for the organization because the success of an organization is influenced by the performance itself. Employees whose performance is good will show high work results while employees with low performance will show low work results. The high improvement of employee performance improvement will increase the performance of the company. Employee performance is related to achievement, results and effort the amount of work to be completed, quality, quality produced, timeliness in completing the task because employees are not only required to complete their work but also must according to the specified time. But in the reality, not all employees are able to do the things mentioned above.

Human capital is one of the important assets in the company that can be developed and improved through education and training. Human resources are an accumulation of the skills and abilities of an employee obtained from experience, training, and education during his tenure to create quality human resources and have good performance. This opinion is supported by the results of the research of Perera \& Weerakkody (2018); Orji, Nwokoye, \& Udu, (2017) which states that human capital has a significant and positive influence on employee performance. Then the opinion of Bapna, Langer, Mehra, Gopal, \& Gupta (2012); Bae \& Patterson (2013) confirmed that additional training modules 
lead to a significant increase in employee performance. In general, the average employee providing additional training courses helps improve employee performance.

To improve the company performance, in addition to human capital, motivation for employees is also needed. High motivation can create a desire to work and provide the best thing to do the job. Therefore company leaders must be sensitive to the desires and needs of their employees so they can motivate them to do their jobs well. According to I. Shahzadi, Javed, Pirzada, Nasreen, \& Khanam (2014); Rakhmalina, Emelda, Hafid, \& Periansya (2017) state that there is a significant and positive relationship between employee motivation and employee performance.

Motivation can improve and foster employee morale and job satisfaction. With the motivation and job satisfaction, employees will work optimally, discipline and honestly in order to achieve high quality and quantity of work so that they can have a good influence on the performance of the company. Research conducted by Hayati \& Caniago (2014); Nduka (2016); Jayaweera (2015) concluded that work motivation influences teacher job satisfaction positively and significantly. Motivation affects teacher performance positively. Then it was also strengthened by research conducted by de Juana-Espinosa \& Rakowska (2018) which concluded that there was a positive relationship between motivation and job satisfaction. The research contributes to a better understanding of job satisfaction for employees.

An organization will be said to be successful if it can effectively and efficiently utilize existing resources, especially existing employees optimally and professionally. For this reason, existing human resources need to be managed well and properly because the success of an institution is determined by the quality of employee performance. Human capital and the success of leaders in providing motivation to employees in carrying out their duties will have an impact on job satisfaction and ultimately employees who are satisfied with their work will improve the performance of the employees themselves. Relationships can be described in the frame of mind that can be seen in the following figure

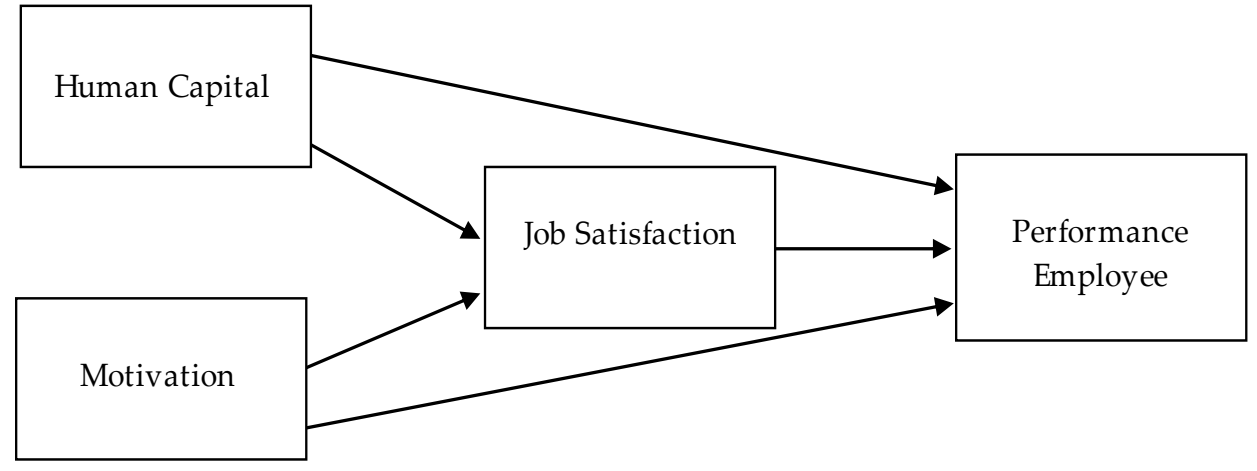

Figure 1 Conceptual Framework

\section{Methods}

The method used in this study literature adopts Systematic Literature Review (SRL) proposed by Xiao \& Watson (2019). SLR is defined as a way of identifying, evaluating and interpreting all available research that is relevant to research questions or domain topics or phenomena that are of interest to researcher. Xiao \& Watson (2019) divided the guidelines for implementing SLR into 3 phases, namely: (1) planning; (2) execution; and (3) analysis of results.

In this literature review, the data sources that will be used are papers available on the website page: (1) Emerald Insight; (2) Wiley InterScience; and (3) Science Direct. The strategy in conducting a search is built through the determination of keywords and synonyms from the focus of the study. Keywords and synonyms are connected to the logical OR and OR connectors.

The paper selection procedure was carried out with the speed reading technique of all primary study candidates. Fast reading is reading the abstraction section of the available paper. Furthermore, 
based on the inclusion and exclusion criteria made, it can be determined whether the paper can be used as a primary study. Based on the planned review, the next step is to execute the plan. Execute search strings on web pages that are used as sources.

Based on the search results on the website page which made the data source produced as many as 5.659 articles which were primary study candidates, then made one, then screened whether the title in the article was the same or not. After screening, 98 articles were the same as the title. Of the 98 articles then screened based on eligibility according to the inclusion and exclusion criteria obtained 27 articles for further review.

\section{Classification of The Literature}

\section{The effect of Human Capital on Employee Performance}

Human capital is the total value of human resources from an organization. The human capital involves all staff in the organization and their ability to complete their work so that $\mathrm{Ng}$ \& Feldman (2013) succeed; Kampkötter (2017); Shafique Awan (2013). Human capital has a positive and significant influence on employee performance indicated by research conducted by Bae \& Patterson, (2013); Chidozie, (2016); Bapna, Langer, Mehra, Gopal, \& Gupta (2012); Rakhmalina, Emelda, Hafid, \& Periansya (2017) a company will produce different performance if managed by different people, therefore, different human resources in managing the same company assets will produce different added values. conducted by (Perera \& Weerakkody, 2018) concluded that there is a strong positive impact of human capital on employee performance. So it was concluded that human capital investment would improve the performance of their employees.

\section{The effect of Human Capital on Employee Satisfaction}

Today, empirical studies related to the relationship between human capital in various aspects and company performance, especially employee performance have experienced such rapid development. Both theoretically and empirically, there is a link between human capital and employee performance, so the company is very important to manage human resources and support the best performance. The best performance of employees is very important for companies to increase company value that can satisfy all parties, especially stockholders. Research conducted by Massingham \& Tam (2015) to find out the relationship between human capital and employee rewards shows that human capital with the dimensions of employee capability, employee satisfaction, employee commitment shows that employee capability has a significant positive effect on pay. This means that the higher the capability of employees, the appreciation of will increase due to increased employee performance. Furthermore, research conducted by Bagri, Babu, Kukreti, \& Smith (2011); Danchev \& Sevinc (2012); Banks (2017) states that human capital has a positive and significant influence on job satisfaction.

\section{The Effect of Work Motivation on Employee Performance}

Ability is inherent in a person since birth and manifested in his actions in work, while motivation is a very important aspect to move the creativity and ability of someone in carrying out the work. Based on research conducted by Shahzadi \& Ahmad, (2014) concluded that there is a significant and positive relationship between employee motivation and employee performance. This is in accordance with the research conducted by Nduka (2016); Muda, Rafiki, \& Harahap (2014); Octaviannand, Pandjaitan, \& Kuswanto (2017) stated that work motivation influences job satisfaction positively and significantly. Motivation affects teacher performance positively. Next is the research conducted by Kiruja (2018); (I. Shahzadi, Javed, Pirzada, Nasreen, \& Khanam (2014); Wilda al Aluf, Sudarsih (2017) revealed that motivation has a positive and significant effect on employee performance.

\section{The Effect of Work Motivation on Employee Satisfaction}

According to Rivai (2011), motivation is a series of attitudes and values that influence individuals to achieve specific things according to individual goals. Motivation determines what employees do, how they do it, and how hard they work. Researchers have begun to consider the role of motivation in generating employee behavior. When employees get good motivation in their work, they will work 
with good will, and when the work is done and appreciated, they will feel their own satisfaction in the employee. Based on the results of research conducted by Regency \& Papua, (2018); Noermijati \& Primasari (2015); Nguyen Cong \& Dung Nguyen Van (2013); Wilda al Aluf, Sudarsih (2017); Khalid, Salim, \& Loke (2011) stated that motivation carried out on employees will have a positive impact on employee job satisfaction itself.

\section{The Effect of Job satisfaction on employee performance}

Job satisfaction is indicated by the employee's assessment of the comparison between expectations and accepted reality. High satisfaction can provide an option to support (favorableness) or not support (unfavorableness) on the work. Of course, the choice will affect how the employee or individual carries out the work. This can be used as an indication that the high job satisfaction of civil servants will be related to the seriousness of these employees in supporting and completing their work happily. Research conducted by Siengthai \& Pila-Ngarm (2016) concluded that job satisfaction was found to be positively related and significant to employee performance. In addition, the interaction effect between job redesign and job satisfaction is found to be positively and significantly related to employee performance. Furthermore, the research conducted by Javed et al., (2014); Awan \& Asghar, (2014); Gupta (2014); Muna, Zain, \& Shaju (2017); Shmailan (2016) reveals that employees who are satisfied with their work will improve their performance in the future.

\section{Results and Discussion}

After a study of the quality of the study, data extraction is then carried out. Data extraction is done by analyzing data based on years of publication, journal, and country.

Table 1 Articles distribution by Year

\begin{tabular}{lll}
\hline Number & Publication Years & Number of Articles \\
\hline 1 & 2013 & 7 \\
\hline 2 & 2014 & 4 \\
\hline 2 & 2015 & 3 \\
\hline 3 & 2016 & 5 \\
\hline 4 & 2017 & 3 \\
\hline 5 & 2018 & 4 \\
\hline 6 & 2019 & 1 \\
\hline & Total & 27 \\
\hline
\end{tabular}

As shown in the Table, the number of review studies has grown rapidly since 2013 and is likely to continue increasing in the next five-year interval. The publication trend of review studies evidences the increasing importance of review type studies in employee performance research and reflects the maturity of the disciplin

Table 2 Article distribution between 2013-2019

\begin{tabular}{llc}
\hline Number & \multicolumn{1}{c}{ Journal } & $\begin{array}{c}\text { Number } \\
\text { of Articles }\end{array}$ \\
\hline 1 & Global Journal of Human Resource Management, & 1 \\
\hline & Academy of Strategic Management Journal, & 1 \\
\hline 3 & Hospitality Review, & 1 \\
\hline 4 & Management of Science. & 1 \\
\hline 5 & International Journal of Research in Business Management, & 1 \\
\hline 6 & Eurasian Journal of Business and Economics, & 1 \\
\hline 7 & European Journal of Management and Business Economics, & 1 \\
\hline
\end{tabular}


Table Cont...

\begin{tabular}{lll}
\hline 8 & International Journal of Learning and Development, & 1 \\
\hline 9 & International Journal of Business and Management. & 1 \\
\hline 11 & International Journal of Human Resource Management. & 1 \\
\hline 13 & International Journal of Advances in Management and Economics, & 1 \\
\hline 14 & Journal of Intellectual Capital. & 1 \\
\hline 15 & International Journal of Business and Social Science. & 1 \\
\hline 16 & International Journal of Advanced Research, & 1 \\
\hline 17 & Centria University Of Applied Sciences. & 1 \\
\hline 18 & Journal of Vocational Behavior & 1 \\
\hline 19 & International Journal of Business and Social Science, & 1 \\
\hline 20 & Journal of Economics, Business E Accountancy Ventura & 1 \\
\hline 21 & International Scientific Research Journal. & 1 \\
\hline 22 & Kelaniya Journal of Human Resource Management & 1 \\
\hline 23 & European Journal of Human Resource Management Studies & 1 \\
\hline 24 & Journal of Business and Management. & 1 \\
\hline 25 & European Jurnal of Business and Management & 1 \\
\hline 26 & Issues in Business Management and Economics, & 1 \\
\hline 27 & Evidence-Based HRM & 1 \\
\hline & Journal of Planning Education and Research. & 1 \\
\hline
\end{tabular}

Table 3 Articles distribution by Country

\begin{tabular}{llc}
\hline No & Country & Number of Articles \\
\hline 1 & Kenya & 3 \\
2 & Indonesia & 2 \\
3 & India & 1 \\
4 & Thailand & 2 \\
5 & Vietnam & 3 \\
6 & Jepang & 2 \\
7 & Bangladesh & 2 \\
8 & Malaysia & 2 \\
\hline & Total
\end{tabular}

Table 3 shows the number of publications by country in ten-year intervals from 2013 to 2019. Overall, 3 review studies were published from Kenya Country, and 4 review studies were published from IndonesiaCountry, review studies were published from India Country, and review studies were published from Vietnam Country.

\section{Limitations}

We found that six different characteristics are associated with employee's performance and human capital, motivation, and job satisfaction; however, none of the included studies was able to control for all of these characteristics simultaneously. Our ability to draw firm conclusions about the effect of individual factors is also limited, owing to contrasting results; different measurements of outcomes; diverse populations and sample sizes. Despite having developed a comprehensive search strategy and having drawn upon databases that were not specific to performance (e.g. ScienceDirect), the majority of the studies found were in the company performance. This limited our ability to explore 
the impact of shift work characteristics across different industries. Quality appraisal to determine the strength of studies according to methodological design is not part of a scoping review (Arksey and O'Malley, 2005) and this limited our conclusions about the strength of the evidence.

\section{Conclusion}

Based on the results of the review literature, it can be conclude that human capital, motivation, and job satisfactionhave a positive and significant effect on employee performance. The results of this review are only a conceptual starting point for starting an integrated discipline. It is realized that this literature study has several shortcomings, including the minimum number of publication provider websites that are used as data sources. In addition to the three websites that are used as data sources in this literature review, there are actually many more websites that provide scientific publications. However, the website cannot be included because of the limited access that the author has. Thus further studies need to be improved on the wider literature sources to gain an understanding of the implementation of concepts in more diverse case studies.

\section{References}

Awan, A. G., \& Asghar, I. (2014). Impact of employee job satisfaction on their performance : a case study of the banking sector in Muzaffargarh district, Pakistan. Global Journal of Human Resource Management, 2(2), 71-94. https://doi.org/10.1017/CBO9781107415324.004

Bae, S. O., \& Patterson, L. (2013). The effect of corporate investment in human capital on employee's performance: Major Korean financial corporation examined. Academy of Strategic Management Journal, 12(2), 55-76.

Bagri, S. C., Babu, A. S., Kukreti, M., \& Smith, S. (2011). Human capital decisions and employee satisfaction at selected hotels in India. Hospitality Review, 29(2), 104-121. https://doi.org/10.1109/ICIP.2004.1421364

Banks, F. (2017). The Influence of Human Capital on Job Satisfaction of Employees of Micro Finance Banks, (01), 20-28.

Bapna, R., Langer, N., Mehra, A., Gopal, R., \& Gupta, A. (2012). Human Capital Investments and Employee Performance: An Analysis of the IT Services Industry. Management Science, 59(3), 641-658. https://doi.org/10.1287/mnsc.1120.1586

Chidozie, G. O. (2016). The human capital development and employee job performance : A study of Double Diamond Plastic manufacturing firm, Aba, Abia State, Nigeria. International Journal of Research in Business Management, 4(6), 41-50. Retrieved from www.impactjournals.us

Danchev, A., \& Sevinc, E. (2012). Willingness to Work, Human Capital, and Job Satisfaction : A Case Study for Turkey. Eurasian Journal of Business and Economics, 5(10), 71-90.

de Juana-Espinosa, S., \& Rakowska, A. (2018). Public sector motivational practices and their effect on job satisfaction: country differences. European Journal of Management and Business Economics, 27(2), 141-154. https://doi.org/10.1108/EJMBE-02-2018-0027

Gupta, I. (2014). Impact of job satisfaction on employee's performance. Scholarly Research Journal for Interdisciplinary Studies, 2(15), 2307-2316.

Hayati, K., \& Caniago, I. (2014). Corrigendum to Islamic Work Ethic: The Role of Intrinsic Motivation, Job Satisfaction, Organizational Commitment, and Job Performance. Procedia - Social and Behavioral Sciences. https://doi.org/10.1016/j.sbspro.2014.05.149

Javed, M., Balouch, R., \& Hassan, F. (2014). Determinants of Job Satisfaction and its impact on Employee performance and turnover intentions. International Journal of Learning and Development, 4(2), 120-140. https://doi.org/10.5296/ijld.v4i2.6094

Jayaweera, T. (2015). Impact of Work Environmental Factors on Job Performance, Mediating Role of Work Motivation: A Study of Hotel Sector in England. International Journal of Business and Management. https://doi.org/10.5539/ijbm.v10n3p271 
Kampkötter, P. (2017). Performance appraisals and job satisfaction. International Journal of Human Resource Management. https://doi.org/10.1080/09585192.2015.1109538

Khalid, K., Salim, H. M., \& Loke, S.-P. (2011). The Impact of Rewards and Motivation on Job Satisfaction in Water Utility Industry. International Conference on Financial Management and Economics, 11, 35-41.

Kiruja, E. M. (2018). Effect of Motivation on Employee Performance In Public Middle-Level Technical Training Institutions In Kenya. International Journal of Advances in Management and Economics, 2(4), 73-82. Retrieved from http://managementjournal.info/index.php/IJAME/article/view/287/275

Massingham, P. R., \& Tam, L. (2015). The relationship between human capital, value creation and employee reward. Journal of Intellectual Capital. https://doi.org/10.1108/JIC-06-2014-0075

Muda, I., Rafiki, A., \& Harahap, M. R. (2014). Factors Influencing Employees ' Performance : A Study on the Islamic Banks in Islamic Science University of the Malaysia University of North Sumatera. International Journal of Business and Social Science.

Muna, A. A., Zain, A. A., \& Shaju, G. D. (2017). Job Satisfaction and Employee Performance: a Theoretical Review of the Relationship Between the Two Variables. International Journal of Advanced Research, 943(1), 1-20.

Nduka, O. (2016). Employee Motivation and Performance. CENTRIA UNIVERSITY OF APPLIED SCIENCES.

Ng, T. W. H., \& Feldman, D. C. (2013). Does longer job tenure help or hinder job performance? Journal of Vocational Behavior. https://doi.org/10.1016/j.jvb.2013.06.012

Nguyen Cong, N., \& Dung Nguyen Van, V. (2013). Effects of Motivation and Job satisfaction on Employees' Performance at Petrovietnam Nghe a Construction Joints Stock Corporation (PVNC). International Journal of Business and Social Science, 4(6), 212-217. https://doi.org/10.11634/216796061302307

Noermijati, N., \& Primasari, D. (2015). The effect of job stress and job motivation on employees' performance through job satisfaction (A study at PT. Jasa Marga (Persero) Tbk. Surabaya Gempol branch). Journal of Economics, Business \& Accountancy Ventura, 18(2), 231. https://doi.org/10.14414/jebav.v18i2.450

Octaviannand, R., Pandjaitan, N. K., \& Kuswanto, S. (2017). Effect of Job Satisfaction and Motivation towards Employee's Performance in XYZ Shipping Company. Journal of Education and Practice.

Orji, O., Nwokoye, E. S., \& Udu, A. A. (2017). Does Government Human Capital Spending Contribute To Human Capital Development?-Evidence From Nigeria. Ponte International Scientific Research Journal. https://doi.org/10.21506/j.ponte.2017.8.10

Perera, K. A. C. N., \& Weerakkody, W. A. S. (2018). The Impact of Human Capital and Social Capital on Employee Performance: A Study of Employees in Small Scale Industry Enterprises in the Western Province of Sri Lanka. Kelaniya Journal of Human Resource Management, 13(1), 38. https://doi.org/10.4038/kjhrm.v13i1.48

Rakhmalina, I., Emelda, E., Hafid, H., \& Periansya, P. (2017). Influence of Motivation and Job Training The Performance of Employees PT. RB Sukasada Palembang. Journal Terapan Manajemen Dan Bisnis, 3(2), 147. https://doi.org/10.26737/jtmb.v3i2.216

Regency, T. B., \& Papua, W. (2018). The Effect Of Motivation, Job Satisfaction And Job Discipline Toward Employee Performance Of Pt. Buma Perindahindo At Lng Tangguh Site. European Journal of Human Resource Management Studies 49-73. https://doi.org/10.5281/zenodo.2040456

Rivai, V. (2006). Manajemen Sumber Daya Manusia Untuk Perusahaan : dari Teori ke Praktik. Edisi Pertama, Penerbit PT. Raja Grafindo Persada, Jakarta. https://doi.org/10.1371/journal.pone.0013666

Shafique Awan, M. A. (2013). The Impact of human capital on Company performance and the mediating effect of employee's satisfaction. IOSR Journal of Business and Management. 
https://doi.org/10.9790/487x-0827682

Shahzadi, E., \& Ahmad, Z. (2014). A Study on Academic Performance of University Students. In Conference Paper. https://doi.org/10.13140/2.1.3949.3126

Shahzadi, I., Javed, A., Pirzada, S., Nasreen, S., \& Khanam, F. (2014). Impact of Motivation on Employee Performance. European Jurnal of Business and Management, 6(23), 159-166. https://doi.org/10.24924/ijabm/2016.04/v4.iss1/76.85

Shmailan, A. (2016). The Relationship between Job Satisfaction, Job Performance and Employee Engagement: An Explorative Study. Issues in Business Management and Economics, 4((1)), 1-8.

Siengthai, S., \& Pila-Ngarm, P. (2016). The interaction effect of job redesign and job satisfaction on employee performance. Evidence-Based HRM, 4(2), 162-180. https://doi.org/10.1108/EBHRM-012015-0001

Wilda al Aluf, Sudarsih, S. and D. M. (2017). Assessing The Impact Of Motivation, Job Satisfaction, And Work Environment On Theemployee Performance In Healthcare Services, 6(10), 337-341.

Xiao, Y., \& Watson, M. (2019). Guidance on Conducting a Systematic Literature Review. Journal of Planning Education and Research. https://doi.org/10.1177/0739456X17723971 